\title{
Nigeria-China Relations: Impact on Power and Development in Nigeria
}

\author{
C. C. Igbokwe \\ Abia State University, \\ P. M. B. 2000, Uturu, Abia State, Nigeria
}

For citation: Igbokwe C. Ch. Nigeria-China Relations: Impact on Power and Development in Nigeria. Vestnik of Saint Petersburg University. Asian and African Studies, 2020, vol.12, issue 1, pp. 141-151. https://doi.org/10.21638/spbu13.2020.110

\begin{abstract}
Nigeria no doubt is one of China's largest markets in Africa. The negative influence Chinese interest in the Nigerian economy has on her energy sector and on development generally is alarming and the rural areas are mostly affected. Rural development is a sine qua non of sustainable national development. Nigerian markets are flooded with Chinese products ranging from generators to rechargeable lamps which are mostly needed to power industries and also generate electricity. Dependency theory provided the theoretical construct for this paper. It was observed that these products such as rechargeable lamps and generating sets may be a welcomed development to cushion the effect of epileptic power supply in the urban centres and lack of electricity in the rural areas but the spillover effects on the Nigerian economy cannot be overemphasised. The paper also discovered the unfortunate situation of how contracts are awarded to Chinese firms in regards to the energy sector. The question which must be critically examined is can a bone be given to a dog for safe keeping? Based on these findings, the paper recommends that the federal government should genuinely and aggressively pursue the issue of rural development especially in terms of rural electrification.

Keywords: relations, rural development.
\end{abstract}

\section{Introduction}

Many years after independence, Nigeria received herculean western string attached aids which have greatly impeded the development of the country. No wonder during the General Sani Abacha's military regime, Beijing's no-strings-attached development projects were increasingly welcomed. This was as a result of Nigeria's leadership growing resentful of Western conditions for aid and investment, and many Nigerians began to question what benefit of economic dependence on the West has achieved for Nigeria. China turned out to become an alternative with the hope of growing the Nigerian economy. Paradoxically, as will be portrayed in this paper, Chinese influence on Nigerian economy has turned a twist in the curve. Much of the local industries have had to unfavourably compete with Chinese firms which have succeeded in driving them out of business hence rendering many jobless.

Nigeria's subsequent adoption of a new approach to international trade in response to balancing traditional Western partners is what resulted in the influx of Chinese firms and goods into the Nigerian market. This phenomenon has adversely affected the power sector, and the textile industry. For the power industry, the Nigerian market is flooded with

(c) Санкт-Петербургский государственный университет, 2020 
all kinds of substandard generators although due largely to the laxities of the Nigerian government to provide for her citizens steady and uninterrupted power supply as well as the inability to sincerely verify the quality of those products. For the textile industry, there is no doubt that Chinese firms have driven underground Nigerian local producers. To state that Nigerian economy is adversely being affected through all these will be the right conclusion. Between 2000 and 2010, annual Nigerian-Chinese trade increased nine-fold, from $\$ 2$ billion to $\$ 18$ billion. Ten major bilateral agreements concerning commerce, agriculture, tourism and security were signed during that period. Nigeria imported more goods from China in 2012 than it did from the U.S. and India combined (Nigeria's number two and three import partners, respectively). Today, more than 200 Chinese firms operate in Nigeria.

Both nations also signed a $\$ 311$ million agreement to develop cooperation in communication and space programmes; which culminated in China helping to develop and launch the Nigerian communication satellite (NigComSat-1) by 2007 to expand cellular and internet network which has since crashed still justifying the doubts of these writers that the economic interest of China is what paramount in the trade relations and not for the development of the Nigerian economy as believed and propagated in some quarters. This paper underscores the need for Nigeria to critically examine Chinese interest in her economy and articulate measures that will enhance balanced trade relations between the two economies [1].

Shoddy or counterfeit products are national problem in Nigeria, Africa's largest economy, where pauperised consumers have few alternatives. Some shoddy goods are benign, like the Chinese-made shirts, trousers and dresses with uneven stitching and stray threads that fill street markets. The China and Nigeria relationship is a complex web of dependency, one replicated in dozens of developing countries around the world. Such ties are integral to China's global strategic ambitions. This ambition also poses new and unpredictable challenges for the Nigerian economy. At the same time, China's highly competitive manufacturing sector has devastated many smaller-scale rivals across Africa, Asia and Latin America [2, pp.27-29]. This should serve as a warning for Nigeria's appetite. Nigeria has become the biggest overseas customer of Chinese construction companies as well as an important market for Beijing, at a time when China's own growth is slowing.

\section{Theoretical Framework}

Linked in with Marxist theories is dependency theory which argues that developed countries, in their pursuit of power, penetrate developing states through political advisors, missionaries, experts and multi-national corporations (MNCs) to integrate them into the capitalist system in order to appropriate natural resources and foster dependence by developing countries on developed countries. This theory best describes the relationship between China and Nigeria and its impact on development of the Nigerian economy.

Dependency theory is the notion that resources flow from a "periphery" of poor and underdeveloped states to a "core" of wealthy states, enriching the latter at the expense of the former. It is a central contention of dependency theory that poor states are impoverished and rich ones enriched by the way poor states are integrated into the "world system". The theory arose as a reaction to modernisation theory, an earlier theory of development which held that all societies progress through similar stages of development, that today's 
underdeveloped areas are thus in a similar situation to that of today's developed areas at some time in the past, and that, therefore, the task of helping the underdeveloped areas out of poverty is to accelerate them along this supposed common path of development, by various means such as investment, technology transfer, and closer integration into the world market. Dependency theory rejected this view, arguing that underdeveloped countries are not merely primitive versions of developed countries, but have unique features and structures of their own; and importantly, are in the situation of being the weaker members in a world market economy [3].

Although dependency theory no longer has many proponents as an overall theory but some writers have argued for its continuing relevance as a conceptual orientation to the global division of wealth [4].

The premises of dependency theory are that:

1. Poor nations provide natural resources, cheap labor, a destination for obsolete technology, and markets to the wealthy nations, without which the latter could not have the standard of living they enjoy.

2. Wealthy nations actively perpetuate a state of dependence by various means. This influence may be multifaceted, involving economics, media control, politics, banking and finance, education, culture, sports, and all aspects of human resource development (including recruitment and training of workers).

3. Wealthy nations actively counter attempts by dependent nations to resist their influences by means of economic sanctions and/or the use of military force.

Dependency theory has been criticized by free market economists such as Peter Bauer and Martin Wolf [5, pp. 169-199].

- Lack of competition. By subsidizing in-country industries and preventing outside imports, these companies may have less incentive to improve their products, to try to become more efficient in their processes, to please customers, or to research new innovations [6, pp. 139-152].

- Sustainability. Industries reliant on government support may not be sustainable for very long, particularly in poorer countries and countries which largely depend on foreign aid from more developed countries.

- Domestic opportunity costs. Subsidies on domestic industries come out of state coffers and therefore represent money not spent in other ways, like development of domestic infrastructure, seed capital or need-based social welfare programs. At the same time, the higher prices caused by tariffs and restrictions on imports require the people either to forgo these goods altogether or buy them at higher prices, forgoing other goods.

- Market economists cite a number of examples in their arguments against dependency theory. The improvement of India's economy after it moved from state-controlled business to open trade is one of the most often cited. India's example seems to contradict dependency theorists' claims concerning comparative advantage and mobility, as much as its economic growth originated from movements such as outsourcing - one of the most mobile forms of capital transfer. The two Koreas provide another example of trade-based development vs autocratic self-sufficiency. When the two states were divided at the end of the Korean War, they possessed roughly identical populations, resources and infrastructure and were at similar 
levels of development. North Korea pursued a policy of import substitution industrialisation as suggested by dependency theory, while South Korea pursued a policy of export oriented industrialisation as suggested by comparative advantage theory. In 2013, South Korea's per capita GDP was 18 times that of North Korea. In Africa, states which have emphasized import-substitution development, such as Zimbabwe have typically been among the worst performers, while the continent's most successful non-oil based economies, such as Eghpt, South Africa and Tunisia have pursued trade-based development [7].

Within the context of this discourse, dependency theory has provided the prism with which to understand the present economic predicament of Nigeria who depends so much on foreign aids but do little but inconsequential to improve her economy. Whoever believe that China is in Nigeria for the development of the host country lack the understanding of the fact that natural recourses and market are the driving economic undertone of Chinese interest in Nigeria. The earlier the drivers of the Nigerian economy understand this reality, the better for her economy. Note, this research is not advocating autocratic self-sufficiency model or a closed economy but aggressive policy of export oriented industrialisation. By increasing the volume of export to compete with level of import wll lead to balanced trade and subsequently ensure economic development.

\section{China-Nigerian Trade Relations: Impact on the Economy}

China's formal trade relations with African countries are traceable to the late 1950s. Prior to this period, their major trading partners were the North African countries, especially Egypt. Driven by the desire for most export of primary products and importation of consumer as well as capital goods from China, Nigeria without considering the cost and implications of welcoming the Asian giant into her market gladly opened her economy to nosedive. Nigeria began exporting primary products such as cocoa beans, rubber, cashew nuts, hide and skin, and some other agricultural products and oil. China on the other hand flooding the Nigerian market with large amounts of low-cost manufactures export meeting with Nigeria local consumer demands that resulted in the declining economy. This also resulted in serious trade imbalances between both sides. Trade imbalance with china has been a structural problem common not to Nigeria alone but also to most African countries. Although China tries to employ the strategy of economic assistance programs as a means assuaging the adverse effects of this imbalance but that hasn't stopped the deterioration of the local industries and as well as the never ever improved epileptic power situation in Nigeria.

According to the China Customs, the bilateral trade volume between China and Nigeria in 2006 reached US $\$ 3.13$ billion, up by 10.6, from 2000 to 2006, among which China's export to Nigeria was US $\$ 2.85$ billion, up by 23.9 , while China's import from $\mathrm{Ni}$ geria was US $\$ 280$ million, down by 47.3 . China had a surplus of US $\$ 2.57$ billion which is seriously unhealthy to the Nigerian economy. China mainly exported motorcycles, machinery equipment, auto spare parts, tyres, chemical products, textiles and garments, footwear, cement, generators, etc [8, pp. 631-645].

There are divergent perceptions of the growing investments by China in Nigeria especially on the possible effects of China's involvement with Nigerian oil. The importance 
of Nigeria to China led to January 2006 signing of the Abuja Memorandum of Understanding (MOU) with Beijing for the Establishment of Strategic Partnership programs to enhance their economic ties. In doing so, Nigeria became the first African country to sign such an agreement with China [9, pp. 1-5]. Despite this MOU, this researcher is skeptical to this partnership benefiting Nigeria in the long run bearing in mind some of results already witnessed in the Nigerian market. China's increasing presence in Nigeria, and elsewhere in Africa, has spurred much speculation about the nature of the emerging partnership model. A national debate across sectors on this partnership will be a healthy exercise and propel more rigorous analysis of what best serves Nigeria's interest in friendly, mutually beneficial relations in trade.

Under the administration of President Goodluck Jonathan, nine memoranda of understanding were signed between Nigeria the Chinese government. This agreement provided Nigeria with some sought of soft loan of $\$ 1.1$ billion loan in exchange for Nigeria agreeing to increase its daily supply of oil to China ten-fold (from 20,000 barrels per day to 200,000$)$ by 2015 [10, pp.3-16].

According to Osakwe, "China is good for Nigeria because there has been an increase in the establishment of infrastructure, strengthening of skills and human capital, and the breaking of colonial interactions with the West [11, pp. 1-34]. This view corroborates the argument of Broadman et al that the emerging "giant" of China is undeniably at the centre of the explosion of Africa- Asian trade and investment, presenting an emblem of a new advancement in South-South commercial affairs [12].

However, in spite of the skyrocketing growth of Nigerian-Chinese trade over the past decades, Nigeria has remained at the bottom while china is continuously on top of the trading ladder. Suffice also to note that despite Chinese trade imperialism in Nigeria the U.S. and some other Western nations like France have continued their neo-colonising trade relations resulting the decline of the Nigerian economy.

It is imperative observe that China's interest in Nigeria is nothing other than access to natural resources and new consumer markets - as it is in the rest of Africa. Clearly, the economic undertones of Chinese relations with Nigeria cannot be overemphasized. Unfortunately the Nigerian market is today flooded with substandard products from China. Paradoxically, most of these products were produced at the instance and specifications of Nigerian business community. The reasons most times adduced for this phenomenon are that Nigerians cannot afford to pay the costly products as well as the interest to keep servicing the market to ensure recurrent turnover. Evidences abound in the telecommunication, textile and in the energy sectors. For example, handsets and batteries, generators, rechargeable lamps and torchlight, etc.

There are yet several factors threaten the prospects for deeper ties between Nigeria and China. Among, include the imperialistic tendencies of foreign investors and the fact that Nigeria has little comparative advantage with China industrialized status. Although Chinese investors maintain a reputation for being less risk-averse than most western trading partners but the risk of being cut in the web of trade imbalance is obvious.

Obviously, economics is the driving force of China's agenda in Nigeria, but it is also imperative to observe that this posture has recently began to shift a little towards embracing a new foreign policy in West Africa particularly that is aimed at supporting the fight against Islamic extremism. China already has pledged support for the Economic Community of West African States (ECOWAS)'s military campaign against Al Qaeda-affiliate 
groups in northern Mali. In their views, African nations should not combat extremism without foreign support and maintained that Beijing "resolutely supports" West African governments and international organizations (such as ECOWAS) in their battle against militant Islamist extremism [13].

While many Nigerians will consider China's growing investment in Nigeria as a welcomed development, others have raised concerns about its impact on the Nigerian economy, bearing in mind the impact Chinese trade and investment has had on other African countries. The Chinese model of importing its own workers to build infrastructure projects, for example, does not and will not augur well with Nigeria.

A number of Nigerians have also voiced objections to the "slave-like" labour conditions in Chinese-operated factories across Nigeria. Attention was first brought to these conditions when 37 Nigerian workers died after being trapped inside a locked Chineseowned factory that caught fire in 2002. Nigeria's trade unions have similarly complained that the ramp up in Chinese imports have eliminated more than 350,000 manufacturing jobs, primarily in the textile sector. Much of the bilateral trade is also "off the record", given that many Chinese imports arrive in Nigeria via the porous borders that Nigeria shares with its neighbors. This exacerbates the already problematic level of corruption in Nigeria.

Bilateral trade reached US $\$ 3$ billion in 2006 - up from $\$ 384$ million in 1998 [14]. During Chinese President Hu Jintao's visit in 2006, China secured four oil drilling licenses and agreed to invest $\$ 4$ billion in oil and infrastructure development projects in Nigeria, and both nations agreed to a four-poin t plan to improve bilateral relations - a key component of which was to expand trade and investments in agriculture, telecommunications, energy and infrastructure development [15]. Furthermore, China agreed to buy a controlling stake in the Kaduna oil refinery that would produce 110,000 barrels per day $\left(17,000 \mathrm{~m}^{3} / \mathrm{d}\right)$. Nigeria also promised to give preference to Chinese oil firms for contracts for oil exploration in the Niger Delta and Chad basin [16]. In 2006, China also agreed to grant a loan of $\$ 1$ billion to Nigeria to help it upgrade and modernize its railway networks [17]. In 2005 Nigeria agreed to supply PetroChina with 30,000 barrels per day $\left(4,800 \mathrm{~m}^{3} / \mathrm{d}\right)$ of oil for $\$ 800$ million. China has also pledged to invest $\$ 267$ million to build the Lekki free trade zone near Lagos - subtly to the interest China because Nigeria has little or nothing of comparative advantage with China. However, the "flooding" of Nigerian markets with cheap Chinese goods has become a worrisome but sensitive economic issue militating adversely against domestic industries. For example, the textile industry in Nigeria has suffered the closure of 65 textile mills and the laying-off of 150,000 textile workers over the course of a decade [18].

\section{China and Energy sector in Nigeria}

Chinese companies are becoming increasingly active in overseas markets, especially in Africa and particularly in Nigeria. The allusion that Chinese projects and financial support contribute to power sector development, extending energy access and facilitating economic growth in Nigeria are questionable when compared to the volume of generators that are imported into the Nigerian market. This section describes China's activity in the Nigeria power sector; by measuring and analysing the engagement of Chinese energy infrastructure companies in the region, it aims to present a better understand the role of China in electricity provision. In the context energy, most pro Chinese writers agree on 
the active role of Chinese companies in Africa's power sector, both in terms of magnitude and impact on new electricity capacity additions, mostly coming from renewable energy, including large hydroelectric plants.

In order to enhance energy access in Africa, the G20 initiated under the Turkish presidency in 2015, and China's 2016 G20 presidency that Chinese companies will be actively involved in Africa's power sector development, the IEA can support and facilitate by helping governments of African countries and assist multilateral co-operation among African economies and beyond in an appropriate, transparent and environmentally sustainable manner. African countries and particularly Nigeria wish to see that this becomes a reality and not just rhetoric. Given Africa's rich energy resources, the potential is huge. Greater global co-operation can deliver benefits for all, ultimately promoting increased energy access and economic growth. In the end, this can only succeed if addressed in a positive way by leaders of African countries [19].

China's involvement in Nigeria is part of Chinese imperialistic agenda - the internationalisation of Chinese companies as well as the government's "going abroad" strategy. It is also imperative to observe at this point that Chinese interest in Nigeria is motivated by the current economic slowdown in China and overcapacity in various sectors. As a result Chinese companies are compelled to search for new markets overseas. Statistics show that over $90 \%$ of Chinese-built power projects in the region are contracted by Chinese stateowned enterprises. Africa's industrialisation and economic development is seen by Chinese stakeholders as important for Chinese exports of manufactured goods in the region. Paradoxically, this expected result is unattainable considering that Chinese firms import their own workforce from home country and few other are usually held and subjected to slave-like condition [20].

In sub-Saharan Africa, the problem lies especially in shortage of supply. Over 635 million people live without electricity in the region. Particularly most rural dwellers don't know what is called electricity. Due to limited infrastructure for generation, Transmission \& Distribution, as a result economic growth is constrained by frequent electricity shortages [21]. According to the IEA New Policies Scenario in the World Energy Outlook, sub-Saharan electricity demand is expected to increase by 2040, demand from industry will double while residential demand will grow by more than five times current levels. At a rate of $6 \%$ per year, electricity demand growth will therefore exceed GDP growth throughout the next 25 years to 2040 [22]. Between 2011 and 2013, Chinese oil companies invested $\$ 73$ billion in oil and gas projects overseas [23]. China's engagement overseas is part of the "going abroad" policy incorporated for the first time in the $10^{\text {th }}$ Five-Year Plan [24]; it also aims to extend internationalisation of Chinese companies. In addition, enlarged Chinese overseas involvement is encouraged under the "Belt and Road" initiative launched by President Xi Jinping in 2014 [25]. It is obvious that its energy engagement in Africa is driven by the need for overseas markets. On paper, China's activities are expected to contribute to power sector development in emerging countries through construction of new generation capacity and new grids. Nigeria for example is still battling with an unending problem of electricity generation transmission and distribution.

In a period of five years 2010-15, Chinese loans and foreign direct investment (FDI) for sub-Saharan Africa power sector development amounted to around $\$ 13$ billion. Most power facilities built by Chinese companies are financed by Chinese stakeholders, essentially through public lending from the Export-Import Bank of China (Exim Bank). Con- 
struction costs of power plants built by Chinese builders are lower overall than in other parts of the globe [26, pp.600-601]. Following from this, epileptic power phenomenon should have been a thing of the past and producers, importers and distributors of Chinese generators should have gone out of business. As long as this situation persists, the implication is that there is sincerity in execution such acclaimed projects and contracts.

Nigeria signed an agreement worth $\$ 80$ bn with Chinese companies to upgrade its oil and gas infrastructure. It expected that this agreement will translate into bolstering Nigeria's economy as it grapples with its worst economic crisis in decades. This memorandum of understanding covers all aspects of Nigeria's energy sector, from rehabilitating decaying refineries and building new pipelines to developing the neglected gas and power sectors. The agreement was reached this year 2017 during the Nigeria's oil minister Emmanuel Ibe Kachikwu's visit to Beijing. In this agreement were 38 Chinese companies were involved [27].

However, it is not clear how the deals would be financed and the implementation is still being waited still adding to our doubt that Chinese interest is for the development of the Nigerian economy rather than for her own strategic interest. Clearly this shows that China is interested in investing in Nigeria's oil and gas sector with the same appetite as that of the west. Nigeria badly needs investment to boost oil production and improve fuel and power supplies for its $180 \mathrm{~m}$ people. In spite of its oil riches, the country imports nearly all of its fuel because its moribund refineries cannot process crude oil. If Chinese investment in this sector is the option, it will be a welcomed development.

Note that if trading partners are asymmetric countries in the sense that they have considerably different technologies and endowments, even if economic integration raises the worldwide growth rate, it may adversely affect the weaker individual countries [28]. By implication therefore Nigeria's optimism that increased Chinese presence in her economy means development is a mirage.

This paper advocates that rather than destroy the so called illegal refineries, the technology can be improved upon and the people encouraged to develop the idea by the government. This is indeed is an indigenous technology that must not be allowed to die rather their developers can even be employed by government and placed on better welfare package/salaries.

\section{Conclusion}

The constraints plaguing Nigerian electrification project is partly traceable the contractors and largely to be blamed on the inability of the government to negotiate, implement and maintain projects. Outside of China, Nigeria must take the issue of her power sector development seriously as the overall success is ultimately dependent upon the leadership. Available information from the Standards Organization of Nigeria show that authorities are trying to stamp out substandard Chinese electric goods, imported power strips and wiring which have inadequate copper to handle Nigeria's 240-volt system. These electrical wires, ubiquitous in new homes and offices, are connected to dozens of fire outbreaks in many homes. Unfortunately, this is still the same country that Nigeria is awarding power sector development contracts. Suffice to state that Nigerian authorities are enmeshed in endemic corruption, making it more difficult to enforce safety standards. 
In the face of all these, Chinese goods are still flooding the Nigerian market and becoming so dominant that consumer have few other choices.

In spite of all this, Nigerian-Chinese economic ties can be expected to continue to grow. China's dependency on Middle Eastern oil and gas is a grave concern for Beijing, given the rising political uncertainty in the region, and rising political risks for foreign investors due to insurgency. In this context, a deeper partnership with Nigeria, one of the world's biggest producers of crude oil, provides China with a more diverse set of options for acquiring oil and gas and other primary products.

Despite all these concerns voiced in this paper and from certain constituencies within Nigeria, most Nigerians are still of the view that China's growing presence is likely more beneficial than harmful. In their views, Western powers that claim a desire to help Nigeria develop are often perceived as insincere, with their own aids being viewed as an apron string to continuously tie Nigeria to an unending debt burden. In this respect, China is seen as non-hypocritical and more respectful of Nigerian peoples' aspirations to manage their own affairs without fear of meddling by a foreign power. The above perception sounds laudable, but the reality is that they are one and same imperialistic mogul.

Nigerian government should also understand that China's growing presence in the country will not inevitably provide solutions to the plethora of domestic challenges that Nigeria faces, especially in the power sector. In fact their continuing presence is a threat to rural development in term of electrification. With the little generating sets rampant in the rural areas government feel reluctant towards rural electrification projects such as they pretend today that the provision of water is no longer government's responsibility because every household now have self provided borehole water. In the end, hide under the guise of accepting that China's number one objective is meeting the responsibility of power sector development without realising that China's strategic interests is for more markets for her finished products. The earlier Nigerian leaders realised this, the better as actions are needed to discourage rural urban migration by providing electricity in the rural areas which in turn will enhance development of these areas.

As much as we accept the assertion that "no man is an island" Nigeria should trade with caution the idea that China is a better option towards providing the much anticipated solution to her power problems. The writers are aware that globalisation encourages interdependence but that does not imply dependency which will be disastrous. The growing economic partnership with China provides average Nigerians with reason for optimism for prosperity but the future is bleak without Nigeria taking her future into her own hands.

\section{References}

1. "China launches Satellite for Nigeria”. MSNBC. 2007, May 14. Available at: www.msnbc.msn.com (accessed: 22.02.2019).

2. Amadasun A.B. China-Nigeria Economic Co-operation: Conceptualization, Contending issues and Prospects and its implications for the West African Sub-Region. 12 EADI General Conference Global Governance for Sustainable Development. Geneva, Switzerland, 2008, pp. 27-29.

3. James P. "Post-Dependency: The Third World in an Era of Globalism and Late Capitalism". Alternatives: Social Transformation and Human Governance, 1997, vol. 22 (2), pp. 205-226.

4. Matias V. "Technology, Finance and Dependency: Latin America Radical Political Economy in Retrospect”. Working Paper No. 2004-06, University of Utah Dept. of Economics, 2004. 
5. So A. Social Change and Development: Modernization, Dependency, and World-Systems Theory. Newbury Park, London, Sage Publication 1990, pp. 169-199.

6. Korotayev A., Zinkina J. On the Structure of of the Present-day Convergence, Campus-Wide Information System, 2014, vol.31, no. 2/3, pp. 139-152.

7. Williams M. The End of the Developmental State? London, Routledge, 2014. 44 p.

8. Taylor I. China's Relations with Nigeria. The Round Table, 2007, vol. 96, no. 392, pp. 631-645.

9. Umejei E. "Another Look at China's Trade Investment in the Country". Daily Independent Lagos, 2011, pp. 1-5.

10. Corkin L., Burke C., Davies M. China's Role in the Development of Africa's Infrastructure. African Studies Program. The Johns Hopkins University Paul H. Nitze School of Advanced International Studies School. Washington, D.C., 2008, pp.3-16.

11. Osakwe A. "China-Nigeria Relations: The Nigerian Niger Delta and Continent Wide Patterns". International Affairs Review, 2012, vol. 1, no. 4, March.

12. Broadman H. G., Isik G., Plaza S., Ye S., Yoshino Y. Africa's Silk Road: China and India's New Economic Frontier. The World Bank for Reconstruction and Development. Washington D. C., 2007, pp. 1-34.

13. Chinese, Nigerian Presidents agree to Promote Strategic Partnership. Available at: www.NEWSGD. com (accessed: 22.03.2019).

14. Taylor I. Sino-Nigerian Relations FTZs Textiles and Oil. China Brief - Jamestown Foundation, 2007, vol. 7 (11).

15. Victoria O. Nigeria: Chinese Government Hands Over US \$12.5 million to Nigeria. Available at: www. allafrica.com (accessed: 22.03.2019).

16. Nigeria gets $\$ 1$ bn China rail loan. Available at: www.bbc.com (accessed: 22.03.2019).

17. Victoria O. Nigeria: Chinese Government Hands Over US \$12.5 million to Nigeria. Available at: www. allafrica.com (accessed: 22.03.2019).

18. IEA (International Energy Agency), World Energy Outlook, OECD/IEA, Paris. 2015a. Available at: www.iea.org (accessed: 22.03.2019).

19. IEA, World Energy Statistics and Balances 2015, OECD/IEA, Paris, 2015c. Available at: www.iea.org (accessed: 22.03.2019).

20. David H.Shinn, Joshua Eisenman China and Africa: A Century of Engaement. USA, University of Pennsylvania Press, 2012. 87 p.

21. IEA, Africa Energy Outlook - A Focus on Energy Prospects in Sub-Saharan Africa. World Energy Outlook Series, OECD/IEA. Paris, 2013a.

22. IEA, Update on Overseas Investments by China's National Oil Companies: Achievements and Challenges Since 2011. OECD/IEA. Paris, 2014b.

23. IEA, Renewable Energy Medium-Term Market Report, OECD/IEA. Paris, 2015.

24. Clover C., Hornby L. China's great game: Road to a new empire. Financial Times, 2014, October 14. Available at: www.ft.com/intl/cms (accessed: 22.03.2019).

25. Oyeranti O., Babatunde A. M., Ogunkola O. E., Bankole A. S. The Impact of China-Africa Investment Relations: The Case of Nigeria. AERC Collaborative Research China-Africa Project, 2010, iss. 8, p. 2.

26. Mohan G., Tan-Mullins May. Chinese Migrants in Africa as New Agents of Development? An Analytical Framework. European Journal of Research, 2009, vol.21, pp.600-601.

27. Grossman G. M., Helpman E. Innovation and Growth in the Global Economy. Cambridge, MA, MIT Press, $1991.191 \mathrm{p}$.

Received: April 18, 2019

Accepted: December 12, 2019

Author's information:

Clement Chimezie Igbokwe - Dr.; chimbest@yahoo.com 


\title{
Китайско-нигерийские отношения: влияние на энергетику и развитие Нигерии
}

\author{
К. Ч. Игбокве
}

Государственный университет Абиа, Нигерия, штат Абиа, Ютуру, П. М. Б 2000

Для цитирования: Igbokwe C. Ch. Nigeria-China Relations: Impact on Power and Development in Nigeria // Вестник Санкт-Петербургского университета. Востоковедение и африканистика. 2020. T.12. Вып. 1. С. 141-151. https://doi.org/10.21638/spbu13.2020.110

Без сомнения, Нигерия является одним из крупнейших рынков Китая в Африке. Настораживает негативное влияние, которое интересы Китая оказали на экономику Нигерии, особенно повлияв на сельские районы. Развитие сельских районов является обязательным условием для долгосрочного национального развития. Нигерийские рынки наполнены китайскими товарами, начиная с генераторов до перезаряжаемых ламп, которые способны генерировать электричество и больше всего необходимы в отраслях энергетики. Теоретической базой данной статьи является теория зависимости. Было замечено, что перезаряжаемые лампы и генераторы могут восприниматься как положительное нововведение, способное смягчить эффект от спорадического электроснабжения в городах и нехватки электричества в деревнях, однако нельзя игнорировать их избыточное влияние на нигерийскую экономику. В статье также рассматривается неблагоприятная ситуация с вручением контрактов китайским фирмам в отраслях энергетики. Вопрос, которым задается статья: может ли кость, которую дали собаке, оставаться в сохранности? В заключение в статье рекомендуется федеральному правительству обратиться к развитию сельских районов, особенно в сфере электрификации. Ключевые слова: отношения, развитие сельских районов.

Статья поступила в редакцию 18 апреля 2019 г., рекомендована к печати 12 декабря 2019 г.

Контактная информация:

Игбокве Клемент Чимизе - д-p; chimbest@yahoo.com 